\title{
THE METHODOLOGY OF DIGITAL SHADOW ECONOMY ESTIMATION
}

\author{
Ligita Gasparéniené, Yuriy Bilan, Rita Remeikiené, \\ Romualdas Ginevičius, Martin Čepel
}

\section{Introduction}

Although following the Regulation No. 549/2013 of the European Parliament and of the Council of 21 May 2013 on the European system of national and regional accounts in the European Union (EU Commission, 2013), EU Member States are not obliged to measure the scopes of non-observed economy in the European system of national accounts, the economists and statisticians stress the need to estimate the scopes of this phenomenon to have reliable and comparable data on the structure and trends of both national and regional economies. In accordance with provision (3) of the Regulation No. 549/2013 of the European Parliament and of the Council of 21 May 2013 (EU Commission, 2013), "citizens of the Union need economic accounts as a basic tool for analysing the economic situation of a Member State or region. For the sake of comparability, such accounts should be drawn up on the basis of a single set of principles that are not open to differing interpretations. The information provided should be as precise, complete and timely as possible in order to ensure maximum transparency for all sectors" (p. 1).

According to the approximate estimations of the report of the global management consulting firm AT Kearney (Schneider \& Kearney, 2013), non-observed economy in Europe today is worth more than 2.1 trillion euro. In the context of nonobserved economy, an important focus is being placed on the soaring scopes of non-observed activities online. Nevertheless, the reliable methodologies that would allow to estimate the actual scopes of this economic phenomenon have not been developed. Bossler and Holt (Bossler \& Holt, 2012) note that absence of the methodologies purposefully developed to estimate the size of non-observed economies online is the key hindrance that complicates investigation and prevention of the cases of illegal activities online. In addition, minding the fact that digital shadow economy is a structural part of the overall shadow economy, it can be presumed that the publically announced figures of the scopes traditional shadow economy may lose their accuracy since the indicators of digital shadow economy are not included in the methodologies of traditional shadow economy estimation. With reference to the report of the OECD (OECD Statistics, 2002), "complete coverage of economic production is a vital aspect of the quality of the national accounts. This exhaustiveness is hard to achieve because of the difficulties in accounting for certain types of productive activities" (p. 3). What is more, differences in estimation methodologies as well as absence of the methodologies to cover all the areas of shadow economy (including digital shadow economy) make it difficult to compare the situation in developed market economies with other economies, or between themselves.

Thus far, scientific studies on the methodologies of shadow economy estimation have covered the comparative analysis of different estimation methods (Georgiou, 2007; Schneider et al., 2015; Schneider \& Williams, 2013 etc.), the comparative analysis of causal variables incorporated in the most popular estimation methods (Buehn \& Schneider, 2012; Teobaldelli, 2011; Teobaldelli \& Schneider, 2012 etc.), and differences in the results that are obtained by employing one or another estimation method (Schneider \& Buehn, 2013; Schneider et al., 2015). Yet the methodologies that would allow to consider the indicators of digital shadow economy have not been developed. Hence, the real size of digital shadow economy remains unestimated, and the perception of how the problems of digital shadow economy can be dealt with remains relatively vague (Holt et al., 2010; Mayayise \& Olusegun Osunmakinde, 2014). For the 
reasons explicated above, the development of the methodology that would incorporate the indicators of digital shadow economy could enable to estimate more accurate scopes of the overall shadow economy, and could supplement currently available methodologies of traditional shadow economy estimation. In accordance with provision (11) of the Regulation No. 549/2013 of the European Parliament and of the Council of 21 May 2013 (EU Commission, 2013), "the possible use of new, automated and real-time data collection methods should be explored" (p. 2). As a result, the following scientific problem is formulated: how to estimate the scope of digital shadow economy?

This article is aimed to develop the methodology of digital shadow economy estimation. For the fulfilment of the defined aim, the following objectives have been raised: 1) to ascertain whether the indicators of digital shadow economy are included in non-observed economy estimates in national accounts and traditional methodologies; 2) to propose the indicators of digital shadow economy; 3 ) to develop and introduce the methodology of digital shadow economy estimation. The methods of the research include systematic and comparative analysis of the scientific literature and adjustment of the MIMIC model.

\section{Are the Indicators of Digital Shadow Economy Included in Non-Observed Economy Estimates in National Accounts and Traditional Methodologies?}

In order to develop a method, which can be employed for estimation of the scopes of digital shadow economy, at first it is purposeful to find out whether any indicators of digital shadow economy are included in non-observed economy estimates in national accounts and traditional methodologies, which are most commonly employed to measure the magnitude of traditional shadow economy.

With reference to the report of the United Nations Economic Commission for Europe (UNECE, 2003), non-observed economy refers to all productive activities that may not be captured in the basic data sources used for national accounts compilation. The above-mentioned activities are treated as production irrespective of being illegal or not, i.e. irrespective being registered at tax, social security, statistical and other public authorities. Illegal economic actions shall be considered as transactions when all units involved enter the actions by mutual agreement. Thus, purchases, sales or barters of illegal drugs or stolen property are transactions, while theft is not.

The EU Member-States are free for making a choice of methods to ensure exhaustiveness of their national accounts. What is more, the EU legislation does not require to measure the size of non-observed economy, but requires to ensure the exhaustiveness of estimated GDP and GNI. For this reason, the size of non-official economy is included in the estimations of GDP.

With reference to the data of Eurostat (Eurostat Database, 2016), the participants of non-observed economy can be categorized as the ones acting in different sectors of economy: - Informal sector (T6 - unregistered units);

- Illegal sector (T7 - unregistered units);

- Other sectors (T8 - other types of units under coverage).

With reference to Schneider and Buehn (2013), Schneider and Williams (2015) and Schneider et al. (2013), the activities of informal sector cover trade, transport, agriculture, construction, repair and renovation of dwellings, repair of motor vehicles and household appliances, private lessons and other personal services. According to Juškienè (2015), the sources used to obtain the data about the scopes of activities in informal sector include HBS, LFS, special purpose surveys, opinion polls, tax and other administrative data.

The activities of illegal sector are considered to be particularly difficult to measure due to difficulties to detect them. These activities include thefts, organised crime, paid protection, prohibited manufacturing and sale of products and/or services, smuggling, dummy transactions, bribery, smuggling, etc. (Schneider et al., 2015).

The main sources employed to obtain the data about the scopes of the activities of this type include police reports, reports of custom authorities, reports of tax inspectorates, crime statistics, public opinion polls and other data (e.g. internet, radio, TV, newspapers), experts' estimates and assumptions (Juškienè, 2015). With reference to OECD (2002) and Juškienè (2015), estimations are made not only for non-declared productive activities, but also for illegal activities, for instance, illegal production, 
import, sales, consumption of illegal drugs, prostitution, trade in illegally produced audio and video products, theft, smuggling, etc. Due to the difficulties of measurement, in many cases, the approximate estimates of illegal activities can be regarded only as indicative rather than accurate (Juškienè, 2015; OECD Statistics, 2002; UNECE, 2003). With reference OECD (2002), only five EU Member-States include the estimates of illegal economy in their published estimates of GDP: Bulgaria - the estimates of drug consumption, Czech Republic - the estimates of prostitution and sales of stolen goods, Estonia - the estimates of prostitution, trade in drugs and audio-video products, Slovakia - the estimates of trafficking, distribution of drugs and prostitution, and the UK - the estimations of smuggled alcohol drinks and tobacco products.

Nevertheless, the general share of these estimates cover the data which is not included in the official statistics not only because activities are illegal, but also for many other reasons, e.g. no obligation to provide the data is established or reliable data is not available. With reference to the recommendations of the EU statistical system in Eurostat (2016), the following types of non-exhaustiveness of the official statistics (i.e. non-exhaustiveness of national accounts) are distinguished:

- N1 - Producer should have registered (underground producer),

- N2 - Illegal producer,

- N3 - Producer is not obliged to register,

- N4-Registered legal person is not included in statistics,

- N5 - Registered entrepreneurs is not included in statistics,

- N6 - Misreporting by the registered producers,

- N7 - Other statistical deficiencies in the data.

As it was noted by Juškienè (2015), not all above-mentioned types of non-exhaustiveness of national accounts refer to hidden activities of producers; they may also be caused by inaccuracies of the reported data, lack of obligation for particular economic agents to register their activities, and so forth. However, lack of the data from digital sector is not included in the list of the types of non-exhaustiveness of the official statistics, neither any indicators of digital shadow economy (whether the ones reflecting non-registered production or illegal economic actions online) are included in the estimates of non-observed economy while presenting the figures of GDP in national accounts.

Further in the research, we will analyse whether any indicators of digital shadow economy are included in the traditional methods of shadow economy estimation. According to Williams (2006), minding the fact that shadow activities by their nature are hidden from public authorities, estimation of their actual scopes is a potentially perplexing and difficult task. Thus far, the methods used to measure the scopes of traditional shadow economy have ranged from direct surveys to indirect methods that are based either on statistical traces or employment of proxy indicators (Juškienè, 2015; OECD Statistics, 2002; Schneider \& Buehn, 2013; Williams, 2009; Williams \& Nadin, 2012; Żelazny, 2015, etc.). The variables employed in different types of direct, indirect methods and latent variable models have been summarised in Tab. 1.

Direct approaches are based on qualitative data, which are collected by employing sample surveys (e.g. consumers' surveys, business surveys, special purpose surveys, microsurveys of informal sector), interviews and in-depth interviews (e.g. interviews with tax auditors, representatives of the authorized public authorities, experts from free market institutes, etc.), expert evaluations, in-depth audits, and compliance methods (Augustinaitis et al., 2009; Juškienè, 2015; Schneider \& Buehn, 2013; Schneider et al., 2015; Williams, 2009; Miciuła, 2015). Sample surveys, different types of interviews, micro-surveys and compliance methods are considered as microeconomic methods since they are aimed at investigation of agents' behaviour, changes in business resources, market structures, and differences between the volumes of consumption and income distribution (Schneider \& Buehn, 2013; Williams \& Nadin, 2012; Williams et al., 2007). The key advantages of direct approach methods in terms of their applicability for estimation of the scopes of shadow economy are their ability to disclose the detailed information about the plausible structure of shadow economy (Schneider et al., 2015) and involve different agents (e.g. consumers, entrepreneurs, representatives of public authorities, tax auditors, independent experts of economics, etc.). The information in Tab. 1 


\begin{tabular}{|c|c|c|}
\hline $\begin{array}{l}\text { Method } \\
\text { (category) }\end{array}$ & Variables & Scientific sources \\
\hline $\begin{array}{l}\text { Sample survey } \\
\text { (direct) }\end{array}$ & $\begin{array}{l}\text { Characteristics of shadow economy participants, } \\
\text { shadow economy determinants, types of goods } \\
\text { and services the most commonly traded in shadow } \\
\text { economy }\end{array}$ & $\begin{array}{l}\text { Williams et al., 2009; } \\
\text { Williams and Nadin, 2012; } \\
\text { Williams and Nadin, 2013; } \\
\text { Gasparénienė et al., } 2017\end{array}$ \\
\hline Interview (direct) & $\begin{array}{l}\text { Characteristics of shadow economy participants, } \\
\text { shadow economy determinants, shadow economy } \\
\text { channels }\end{array}$ & $\begin{array}{l}\text { Fethi et al., 2006; } \\
\text { Williams and Nadin, 2012; } \\
\text { Putniš and Sauka, 2014 }\end{array}$ \\
\hline $\begin{array}{l}\text { Expert evaluation } \\
\text { (direct) }\end{array}$ & $\begin{array}{l}\text { Prognosticated total size of shadow economy as } \\
\text { a percentage of GDP, prognosticated size of shadow } \\
\text { economy in particular sectors or sector groups, } \\
\text { sectors with the largest scopes of shadow economy, } \\
\text { characteristics of shadow economy participants, types } \\
\text { of goods and services the most commonly traded in } \\
\text { shadow economy }\end{array}$ & $\begin{array}{l}\text { Augustinaitis et al., 2009; } \\
\text { Williams and Nadin, } 2012\end{array}$ \\
\hline $\begin{array}{l}\text { Micro-survey } \\
\text { (direct) }\end{array}$ & $\begin{array}{l}\text { Business income, expenditure, tax rate, the share of } \\
\text { taxes in the total expenditure, electricity consumption } \\
\text { quantities }\end{array}$ & Georgiou, 2007 \\
\hline $\begin{array}{l}\text { In-depth audit } \\
\text { (direct) }\end{array}$ & $\begin{array}{l}\text { Overall tax rate, the share of taxes in the total } \\
\text { business and household expenditure, tax return, } \\
\text { national account exhaustiveness }\end{array}$ & $\begin{array}{l}\text { Schneider and Buehn, } \\
\text { 2013; AT Kearney, 2013; } \\
\text { Schneider et al., 2015; } \\
\text { Juškienè, } 2015\end{array}$ \\
\hline $\begin{array}{l}\text { GDP } \\
\text { discrepancies } \\
\text { (indirect) }\end{array}$ & National income and national expenditure & $\begin{array}{l}\text { Williams et al., 2007; } \\
\text { Georgiou, 2007; Sookram } \\
\text { et al., 2009; Hatipoglu } \\
\text { and Ozbek, 2011; } \\
\text { Schneider et al., } 2015\end{array}$ \\
\hline $\begin{array}{l}\text { Transaction } \\
\text { method (indirect) }\end{array}$ & $\begin{array}{l}\text { Velocity of money, the value of total transactions, } \\
\text { prices, official GNP }\end{array}$ & $\begin{array}{l}\text { Williams, 2009; Schneider } \\
\text { and Buehn, 2013; Putniš } \\
\text { and Sauka, 2014 }\end{array}$ \\
\hline $\begin{array}{l}\text { Currency ratio } \\
\text { method (indirect) }\end{array}$ & $\begin{array}{l}\text { Currency demand, proportion of wages and salaries in } \\
\text { national income, income per capita, interest rate (paid } \\
\text { on savings deposit), ratio of cash holdings to deposit } \\
\text { accounts, average tax rate, the number of the issued } \\
\text { credit and debit cards as a substitute for cash }\end{array}$ & $\begin{array}{l}\text { Georgiou, 2007; Fethi et } \\
\text { al., 2006; Williams and } \\
\text { Nadin, 2012; Schneider } \\
\text { and Buehn, } 2013\end{array}$ \\
\hline $\begin{array}{l}\text { Electricity } \\
\text { consumption } \\
\text { method (indirect) }\end{array}$ & $\begin{array}{l}\text { Electricity consumption, GDP; electricity consumption } \\
\text { in households per capita, real consumption of } \\
\text { households without electricity consumption per capita, } \\
\text { real price of consumption of } 1 \mathrm{kWh} \text { of residential } \\
\text { electricity, relative frequency of months with the } \\
\text { need of heating, the ratio of energy sources other } \\
\text { than electric energy, the ration of the sum of paid } \\
\text { personal income, corporate profit and taxes on } \\
\text { goods and services to GDP, the ratio of public social } \\
\text { welfare expenditures to GDP, the sum on number of } \\
\text { dependants over } 14 \text { years and of inactive earners }\end{array}$ & $\begin{array}{l}\text { Kaufmann and Kaliberda, } \\
\text { 1996; Lacko, 1998; } \\
\text { Schneider and Buehn, } \\
\text { 2013; Schneider and } \\
\text { Buehn, } 2016\end{array}$ \\
\hline
\end{tabular}




\begin{tabular}{|c|c|c|}
\hline $\begin{array}{l}\text { Sun } \\
\text { esti }\end{array}$ & $\begin{array}{l}\text { ary of the variables employed in different meth } \\
\text { tion - Part } 2\end{array}$ & s of shadow economy \\
\hline $\begin{array}{l}\text { Employment } \\
\text { (labour) } \\
\text { discrepancies } \\
\text { (indirect) }\end{array}$ & Total labour force rate, labour participation rate & $\begin{array}{l}\text { Sookram et al., 2009; } \\
\text { Schneider and Buehn, } \\
2013 \text {; Schneider et al., } \\
2015\end{array}$ \\
\hline $\begin{array}{l}\text { National } \\
\text { accounting } \\
\text { aggregates } \\
\text { (indirect) }\end{array}$ & $\begin{array}{l}\text { Gross output, value added, illegal transactions } \\
\text { with tobacco, alcohol, drugs and sexual services, } \\
\text { production, imports, intermediate and final } \\
\text { consumption, exports }\end{array}$ & $\begin{array}{l}\text { AT Kearney, 2013; } \\
\text { Juškiené, } 2015\end{array}$ \\
\hline $\begin{array}{l}\text { MIMIC (latent } \\
\text { variable model) }\end{array}$ & $\begin{array}{l}\text { Share of direct taxation, share of indirect taxation } \\
\text { and social security contribution, state regulation, } \\
\text { tax morale, unemployment quota, GDP per capita, } \\
\text { employment quota, average working time per week, } \\
\text { change of local currency per capita }\end{array}$ & $\begin{array}{l}\text { Schneider and Buehn, } \\
\text { 2013; Trebicka, 2014; } \\
\text { Schneider et al., 2015; } \\
\text { Schneider and Buehn, } \\
2016\end{array}$ \\
\hline $\begin{array}{l}\text { DGE (latent } \\
\text { variable model) }\end{array}$ & $\begin{array}{l}\text { Household utility, consumption and leisure, household } \\
\text { capital units, returns to scale production, total factor } \\
\text { productivity, tax rate }\end{array}$ & $\begin{array}{l}\text { Elgin and Oztunali, 2012; } \\
\text { Elgin and Schneider, } \\
2013\end{array}$ \\
\hline
\end{tabular}

shows that the methods of direct approach basically consider household (characteristics of shadow economy participants, shadow economy determinants, types of goods and services the most commonly traded in shadow economy, shadow economy channels), business (business income, expenditure, tax rate, the share of taxes in the total expenditure, tax return, electricity consumption quantities) and general economic (prognosticated total size of shadow economy as a percentage of GDP, prognosticated size of shadow economy in particular sectors or sector groups, sectors with the largest scopes of shadow economy) indicators. In spite of a wide range of the indicators, direct approach methods earn much scientific criticism for flaws and unreliability of the data (e.g. representatives of hidden population groups may be afraid or unwilling to disclose the truth (Schneider \& Buehn, 2013) as well as for sensitivity of the final results to formulation of the questions (Schneider et al., 2015), and applicability only for smallscale studies rather than for acquisition of the general results in an industry, a state or a region (Herwartz et al., 2015). What is more, as it was noted by Williams et al. (2006), final demand usually accounts for just two-thirds of total spending. Hence, employment of direct approach methods may determine data inaccuracies, in particular for estimations of the scope of shadow economy, which are expressed in numbers since these numbers reflect just subjective opinion of the respondents, but are not based on any objective criteria. Inclusion of any digital shadow economy indicators has not been observed.

In the absence of direct survey methods and with a view to avoiding data inaccuracies or dependency on subjective opinions, economists rely on indirect approach methods, which, contrary to the above-described direct approach methods, are macroeconomic methods since they are based on comparison of different general economic and non-economic indicators, such as GDP, unemployment rate, the number of small and medium enterprises in an industry, household budget data, etc. (Schneider \& Buehn, 2013; Schneider et al., 2015; Simionescu et al., 2017; Sookram et al., 2009; Williams et al., 2007, Ključnikov et al., 2016). Indirect approach methods lean on quantitative data, and the most common indirect methods, which are most commonly employed for estimations of the magnitude of shadow economy, cover income and expenditure methods (e.g. GDP discrepancies, income/expenditure discrepancies, consumer expenditure, input-output comparisons (including ratios of input to output in an industry), the commodity flow, per capita output and value added data, etc.) (Schneider \& Buehn, 2013; Schneider et al., 2015; Sookram et al., 2009; Williams et al., 2007 etc.) and non-monetary 
methods (labour input method, (un)employment rate discrepancies, population censuses, ranking, electricity consumption method, detection-controlled estimation, the number of small and medium enterprises, comparisons of the data on similar activities from various data sources, etc.) (Kaufmann \& Kaliberda, 1996; Lackó, 1998; Schneider \& Buehn, 2013). The data in Tab. 1 shows that indirect approach methods are based on evaluation of general economic indicators (national income and national expenditure balance, consumption rate, value added, imports, exports, prices, interest rate, proportion of wages and salaries in national income, income per capita, average tax rate, corporate profit and taxes on goods and services to GDP, the ratio of public social welfare expenditures to GDP, the sum on number of dependants over 14 years and of inactive earners, the ratio of the sum of paid personal income), general monetary indicators (velocity of money, currency demand), money turnover indicators (ratio of cash holdings to deposit accounts, the value of total bank transactions, the number of the issued credit and debit cards), electricity and energy consumption indicators (overall electricity consumption, electricity consumption in households per capita, real consumption of households without electricity consumption per capita, real price of consumption of $1 \mathrm{kWh}$ of residential electricity, relative frequency of months with the need of heating, the ratio of energy sources other than electric energy) and labour market indicators (total labour force rate, labour participation rate). With reference to Schneider and Buehn (2013), the main advantage of the methods of indirect approach is that their ability to provide an insight in the indicators, which reflect the changes in the magnitude of shadow economy over the time. Nevertheless, indirect methods are criticized for the provision of crude and unreliable estimates, a narrow scale of applicability, data disparities and discrepancies (Schneider \& Buehn, 2013; Schneider et al., 2015; Williams, 2009; Williams, 2010; Williams \& Nadin, 2012). The indicators of digital shadow economy are not included in indirect methods of shadow economy estimation.

Finally, latent variable models consider the mixture of general economic (GDP per capita), taxation (share of direct taxation, share of indirect taxation and social security contribution), legal (state regulation), societal (tax morale), labour market (employment quota, unemployment quota, average working time per week) and monetary (change of local currency per capita) indicators (i.e. MIMIC model) (Schneider \& Buehn, 2013; Schneider et al., 2015; Trebicka, 2014; Galloppo et al., 2015) or are based on a two-sector (household and business) dynamic general equilibrium which unites such indicators as household utility, consumption and leisure, household capital units, business returns to scale production, total factor productivity, and tax rate (Elgin \& Oztunali, 2012; Elgin \& Schneider, 2013). Among many possible advantages of these models is consideration of a comparatively wide dataset (Elgin \& Schneider, 2013). However, they are criticised for reliance on the use of national income statistics (Elgin \& Schneider, 2013), inability to distinguish the causes of non-observed economy (Schneider et al., 2015), and high probability of double counting (Juškienè, 2015). The indicators of digital shadow economy are not included in latent variable models of shadow economy estimation.

Summarising, although the size of nonofficial economy is included in the estimations of GDP, and scientific literature offers a variety of the methodologies developed to estimate the size of traditional shadow economy, no indicators of digital shadow economy (whether the ones reflecting non-registered production or illegal economic actions online) are included in the estimates of non-observed economy while presenting the figures of GDP in national accounts. Similarly, no determinants of digital shadow economy are incorporated in traditional methods of shadow economy estimation either in international or national methodologies. Hence, the methods of traditional shadow economy estimation do not reflect the share of digital shadow economy in the overall size of shadow economy. For this reason, in order to complement the theory of shadow economy, it is purposeful to identify the plausible indicators of digital shadow economy.

\section{Proposed Indicators of Digital Shadow Economy}

Scientific literature lacks the studies on the topic of digital shadow economy. Gasparènienè and Remeikienè (2015) identified the differences between traditional and digital shadow economies. The authors established that strive 
for profit and resources is characteristic to both traditional and digital shadow economy. The profits (revenues) earned in both economies are invested in merchandise, technics and other means that ensure business continuity. Another similarity is that in both traditional and digital shadow payments are and can be performed not only in cash.

The results of the expert evaluation on plausible indicators of digital shadow economy in Lithuania (the results of the evaluation have not still been published) revealed that an approximate size of digital shadow economy can be reflected by employing such indicators as volumes of payments in cryptocurrencies (e.g. Bitcoins), non-cash transfers via online payment platforms, and monetary value of the parcels for which no custom duties are paid.

By their scopes in the finance market, Bitcoins can be treated as the most widely spread cryptocurrency. With reference to the definition, proposed by the European Central Bank (Vanini, 2012), Bitcoin is an unregulated digital currency. To a certain extent, it resembles electronic money, in particular, software money, which in contrast to hardware money, can be used on the Internet. As the other kinds of cryptocurrencies, Bitcoins employ crypto techniques, and the software of the open code allows to control and change Bitcoin codes. Bitcoin network is composed of numerous computers linked by the Internet. This network allows to perform the number of sophisticated mathematical procedures that influence the demand for Bitcoins in the market and promote the certainty of transfers (Ciaian et al., 2016). With reference to Galdikienè (Duygun Fethi et al., 2006), Bitcoins are gaining their popularity in the countries with high inflation or strict restrictions of capital movement. Following the data of the European Central Bank (Vanini, 2012) and the results of the research, carried out by Eyal and Sirer (2014), Siddik et al. (2016) usage of cryptocurrencies in international settlements is linked to particular risks, such as loss of money in cryptocurrency exchange, steals of money from the digital wallet, lack of protection while using a cryptocurrency as a payment method, fluctuations of value which may significantly drop and even reach zero, obligations to comply with particular tax regulations, etc. The findings of the European Bank were confirmed by Simser (2015), who notes that the usage Bitcoins is linked to higher risks of steals and losses. Nevertheless, the author disproves anonymity as one of the features attributable to Bitcoins.

Štitilis and Laurinaitis (2008) note that electronic settlements are the phenomenon of e-banking in 21st century. In general innovations had the impact on banking sector (Stachova et al., 2017; Cicekli, 2016). Rapid development of IT alongside the strive of commercial banks to bring a bank closer to a customer have determined the spread of electronic settlements (Slozko \& Pelo, 2014; Musa, 2010). A comprehensive research conducted by Zandi et al. (2013) disclosed that usage of e-payments determines nearly 0.8 percent of GDP increase in developing countries, and 0.3 percent of GDP increase in developed countries. With reference to Štitilis and Laurinaitis (2008) and Zandi et al. (2013), financial operations in virtual space should be considered as an important determinant of economic growth. Non-cash payments are beneficial since they provide a faster access to financial resources and reduce the scopes of shadow economy. Nevertheless, some researchers note that non-cash payments via online platforms not only fail to reduce the scopes of shadow economy, but also make preconditions for digital shadow economy (Lithuanian Free Market Institute (LFMI, 2013). Such assumptions are made minding appearance of some alternative measures of settlement (for instance, "Revolut" payment cards) in financial markets.

\section{Estimation of the Multitude of Digital Shadow Economy}

In spite of some criticism (Elgin \& Schneider, 2013; Juškienè, 2015; Schneider et al., 2015), MIMIC latent variable model is considered the most comprehensive methodology of shadow economy estimation. Hence, we can adjust it to estimation of the multitude of digital shadow economy. Digital shadow economy is considered as a latent variable, which, on one side, is related to the set of observed indicators (this way, the changes in the multitude of digital shadow economy are revealed), and on the other side - to the set of causal variables, which have a considerable impact on the multitude of the researched phenomenon. When a sufficient quantity of indicative and causal data is available, the model is developed by employing pretty standard procedures of econometrics. 
Digital shadow economy (ń) is a scalar variable, which is linearly described by a set of directly observed variables $\mathrm{X}_{1}, \mathrm{X}_{2}, \ldots, \mathrm{X}_{\mathrm{q}}$ and

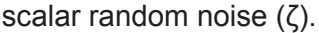

$$
\dot{\eta}=Y_{1} X_{1}+Y_{2} X_{2}+\ldots Y_{q} X_{q}+\zeta
$$

Latent (hidden) variable (ท́), in turn, directly describes endogenous variables $Y_{1}, \zeta Y_{2}, \ldots, Y_{p}$, which are dependent on the levels of scalar noise $\varepsilon_{1}, \varepsilon_{2}, \ldots, \varepsilon_{\mathrm{p}}$ :

$$
\begin{gathered}
y_{1}=\lambda_{1} \dot{\eta}+\varepsilon_{1} \\
y_{2}=\lambda_{2} \dot{\eta}+\varepsilon_{2} \\
\quad \ldots) \\
y_{p}=\lambda_{p} \dot{\eta}+\varepsilon_{p}
\end{gathered}
$$

Structural noise $(\zeta)$ and estimation errors $\varepsilon$ have a normal distribution and are linearly independent. Then, the following marking is introduced:

$\mathrm{X}^{\top}=\left(\mathrm{x}_{1}, \mathrm{x}_{2}, \ldots, \mathrm{x}_{\mathrm{q}}\right)-$ observed exogenous variables (causes);

$Y^{\top}=\left(Y_{1}, Y_{2}, \ldots, Y_{q}\right)-$ structural parameters (structural model);

$\mathrm{y}^{\top}=\left(\mathrm{y}_{1}, \mathrm{y}_{2}, \ldots, \mathrm{y}_{\mathrm{q}}\right)-$ observed endogenous variables (indicators); $\lambda^{\top}=\left(\lambda_{1}, \lambda_{2}, \ldots, \lambda_{q}\right)-$ structural parameters (estimation model);

$\varepsilon^{\top}=\left(\varepsilon_{1}, \varepsilon_{2}, \ldots, \varepsilon_{\mathrm{q}}\right)-$ estimation errors;

$v^{\top}=\left(v_{1}, v_{2}, \ldots, v_{q}\right)$ - standard deviation of estimation errors.

Formulas (1) and (2) can be rewritten as:

$$
\dot{\eta}_{t}=Y^{T} x_{t}+\zeta_{T}
$$

and

$$
y_{t}=\lambda \dot{\eta}_{t}+\varepsilon_{t}
$$

It is presumed that $\mathrm{E}\left(\zeta \varepsilon^{\top}\right)=0, \mathrm{E}\left(\zeta^{2}\right)=\sigma^{2}$, and $\mathrm{E}\left(\varepsilon \varepsilon^{\top}\right)=\Theta^{2}$.

$\Theta_{p x p}$ refers to a diagonal matrix with $v$, which is located in its diagonal.

The model can be converged into a reduced form, i.e. a function of observed variables:

$$
y=\lambda\left(Y^{T} x+\zeta\right)+\varepsilon=\Pi x+v
$$

Here $\Pi=\lambda Y^{\top}$, and $v=\lambda \zeta+\varepsilon$.

This way, the matrix of model covariation is developed:

$$
\Sigma=\left(\lambda\left(\mathrm{Y}^{\mathrm{T}} \Phi \mathrm{Y}+\psi\right)\right) / \Phi \mathrm{Y} \lambda^{T}+\Theta_{\varepsilon} \lambda \mathrm{Y}^{T} \Phi / \Phi
$$

\section{Fig. 1: General structure of the MIMIC model}

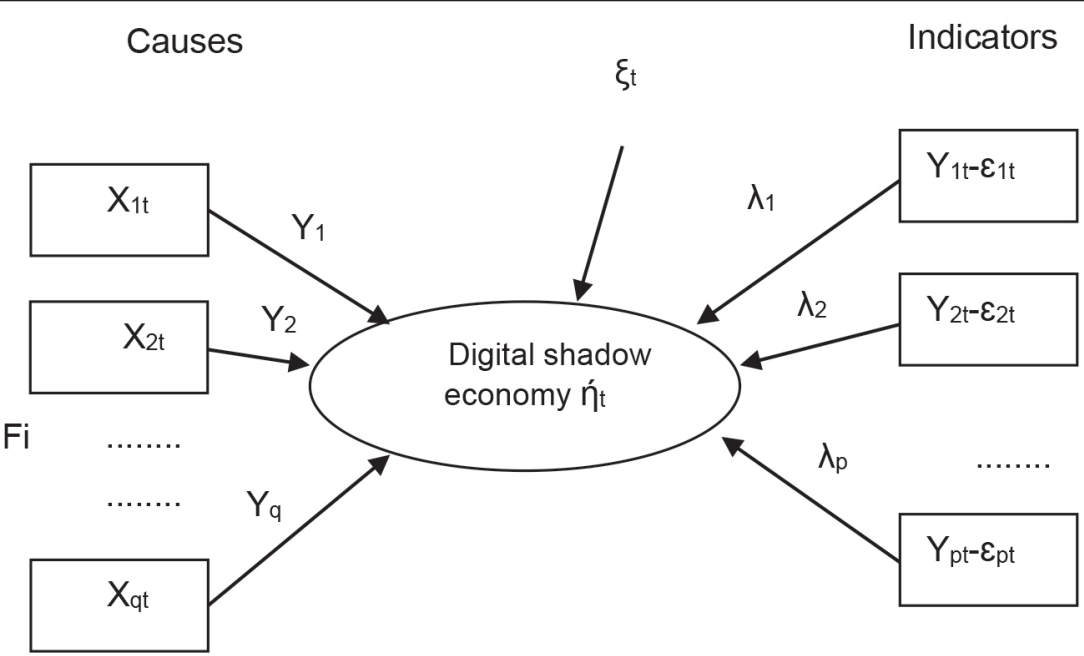


Latent (hidden) variable (ń) is invisible, and its value remains unknown. The other parameters of the model have to be evaluated by analysing the links between the observed variables in the dispersion and covariation. The main aim is to find the values of parameters $Y$ and $\lambda$, and the estimate $\Sigma$.

Interaction between causal variables $X_{q}$, multitude of shadow economy (i.e. latent variable ń), and indicative variables $Y_{p}$ over a particular period has been depicted in Fig. 1.

In this research, the structural model is related to latent variable $n$ (the index of shadow economy) and its causal determinants $X_{q}$ $\left(X_{1}\right.$ - access to the Internet and a computer in households; $X_{2}-$ non-cash payments; $X_{3}-$ introduction of innovative market instruments (e.g. "Revolut" card)). Considering a random variable $\zeta$, it can be expressed as:

$$
\dot{\eta}=Y_{I} X_{1}+Y_{2} X_{2}+Y_{3} X_{3}+\zeta
$$

On the other hand, the estimation model links latent variable $n$ with its indicators $\left(Y_{1}-\right.$ non-cash money transfers via online platforms; $\mathrm{Y}_{2}$ - frequency and amounts of payments in cryptographic currencies; $Y_{3}-$ parcels for which no taxes (or custom duties) are paid (i.e. noncash settlements are made)) by considering random errors $\varepsilon$ :

$$
\begin{aligned}
& y_{1}=\lambda_{1} \dot{\eta}+\varepsilon_{1} \\
& y_{2}=\lambda_{2} \dot{\eta}+\varepsilon_{2} \\
& y_{3}=\lambda_{3} \dot{\eta}+\varepsilon_{3}
\end{aligned}
$$

By incorporating the above-described variables, we can develop an exemplary MIMIC 3-1-3 model (see Fig. 2).

Numbers 3-1-3 mark that 3 causal variables, and 3 indicators are included in the model.

Household access to the Internet and IT, non-cash payments, and introduction of financial innovation are considered as the basic causes of digital shadow economy. With reference to the statistical data, over the first quarter of 2016, 72 percent of Lithuanian people had their personal computers at home; 73 percent of Lithuanian people had access to the Internet. In comparison to 2015 , these figures grew by 4 and 5 percent respectively, which shows that an increasing number of Lithuanian population rely on online settlements while

\section{Fig. 2: General structure of MIMIC 3-1-3 for estimation of the size of digital shadow economy}

Causes $X_{t}\left(X_{1}, X_{2}, X_{3}\right) \quad$ Indicators $Y_{t}\left(Y_{1}, Y_{2}, Y_{3}\right)$

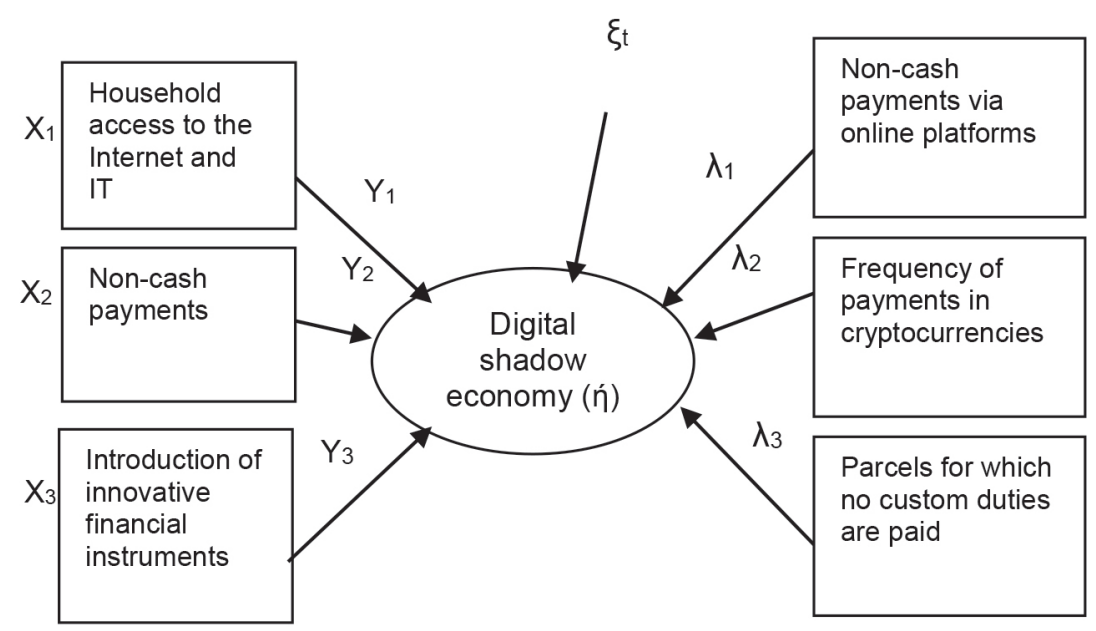


paying for various goods/services (Lithuanian Department of Statistics, 2016). Non-cash payments (credit transfers, direct online debits, payments in debit cards, e-money, e-transfers, etc.) are promoted by central banks with the aim to reduce the size of shadow economy. Nevertheless, the economic estimations reveal the opposite trends: according to LFMI (2013), "the statistics show that a positive correlation between shadow economy as a part of GDP, and the size of e-settlements per capita can be observed in the EU member states, although the correlation is not unambiguous, and some exceptions, for instance, Estonia, can be found" (p. 2). Since the impact of non-cash payments as of a measure of shadow economy reduction has not been proved, they can be attributed to the causes of digital shadow economy. Finally, digital shadow economy can be considered to be caused by introduction of innovative financial instruments. Financial markets have started to accept payment cards (e.g. "Revolut"), which allow to cash money for free both in Lithuania and abroad; the cards are issued without cost, and they assure a comparatively high level of safety. However, the factor of convenience often makes online settlement platforms a favourable environment for transfers of "dirty money". For instance, "Revolut" consumers have to confirm their identities only in case contributions to the account exceed 1,000 euro. Therefore, it is a perfect opportunity to make transactions related to non-taxable income.

The main indicators that could explain the size of digital shadow economy include non-cash payments via online platforms (e.g. Payza, Paysera, PayPal, etc.), frequency of payments in cryptocurrencies, and monetary value of the parcels for which no custom duties are paid. With reference to non-official statistics (LITAWeb, 2013) from June to December 2015, 10.46 percent of Lithuanian consumers chose payments by Paypal; the share of contributions collected by Paypal amounted to 11.53 percent. From January to October 2016, payments by Paypal were chosen by nearly 12.2 percent of Lithuanian consumers, and the share of contributions collected by Paypal exceeded 15.62 percent. Hence, the statistical data above reveal the trends of the rapid spread of online payment platforms.

Another indicator of digital shadow economy is frequency of payments in cryptocurrencies.
A cryptocurrency is a unit of online settlements. It does not have any physical shape; it is maintained electronically and generated by consumers themselves. There are no particular people or institutions that are engaged in issuance of cryptocurrencies. Bitcoins are considered to be the most popular cryptocurrency all over the world. Since introduction of Bitcoin in 2009, the price of this cryptocurrency remained comparatively stable until January 2013, when it reached its maximum value of approximately 20 U.S. dollars. Afterwards, a monthly price growth could be observed until October 2013, when the price reached 198 U.S. dollars. This nearly tenfold increase in Bitcoin value proved to be insignificant in comparison to the price rally in November 2013, when the threshold of 1,100 U.S. dollars per coin was broken. Since then, the Bitcoin price remains in a downtrend, and Bitcoin was valued at 430.05 U.S. dollars as of December 2015. As of February 2015, there were 329 Bitcoin ATMs worldwide. The countries with the highest number of Bitcoin ATMs covered United States (111), Canada (61), Australia (20) and United Kingdom (19) (Statista Database, 2016). In Lithuania, payments in Bitcoins are also getting increasingly popular. Unfortunately, the statistical data on the value of payments in this cryptocurrency are hardly available.

The third indicator of digital shadow economy is monetary value of the parcels for which no custom duties are paid. For instance, if a person orders a good from a third country and pays for it in Bitcoins, he or she gets this good via customs. If no custom duties are paid for delivery (import) of this good, then the monetary value of such parcels can be considered as an indicator of digital shadow economy.

\section{Conclusions}

Summarising, the following conclusions can be made:

1. The analysis of the scientific literature has revealed that traditional methods of shadow economy estimation do not include the indicators that would allow to measure the size of digital shadow economy. This inaccuracy distorts the official figures of the magnitude of shadow economy since a substantial share of shadow activities are transferred to electronic spaces in the form of electronic money.

2. The analysis of most commonly employed shadow economy estimation methods has 
disclosed that in spite of some criticism, the MIMIC model can be considered the most comprehensive method of shadow economy estimation since it covers both causals and indicators of the researched phenomenon.

3. Causal variables, which can explain the spread of digital shadow economy, include household access to the Internet and IT, non-cash payments, and introduction of innovative financial instruments. The indicators of digital shadow economy cover non-cash payments via online platforms, frequency of payments in cryptocurrencies, and monetary value of the parcels for which no custom duties are paid.

4. In order to empirically verify applicability of the new model, which is proposed for estimation of the size of digital shadow economy, the numerical values of the abovementioned causal variables and indicators are necessary. Unfortunately, official statistical databases do not contain all types of the data. In some cases (e.g. concerning frequency of payments in cryptocurrencies), the data are not accumulated at all. Hence, for further research in this area, the authors are going to focus on accumulation of the necessary statistics, which would allow to verify practical applicability of the new model and specify the size of the overall shadow economy in particular countries.

This work was supported by the Research Council of Lithuania (grant number MIP-15642).

\section{References}

Augustinaitis, A., Rudzkienè, V., Petrauskas, R. A., Dagytè, I., Martinaitytè, E., Leichteris, E., \& Žilionienè, I. (2009). Lietuvos e. valdžios gairès: ateities jžvalgu tyrimas. Kolektyviné monografija. Mykolo Romerio Universitetas.

Bossler, A. M., \& Holt, T. J. (2012). Patrol officers' perceived role in responding to cybercrime. Policing: an international journal of police strategies \& management, 35(1), 165-181. doi:10.1108/13639511211215504.

Buehn, A., \& Schneider, F. (2012). Shadow economies around the world: novel insights, accepted knowledge, and new estimates. International Tax and Public Finance, 19(1), 139-171. doi:10.1007/s10797-011-9187-7.

Ciaian, P., Rajcaniova, M., \& Kancs, D. A. (2016). The economics of BitCoin price formation.
Applied Economics, 48(19), 1799-1815. doi:10.1080/00036846.2015.1109038.

Cicekli, E. (2016). Graduate skills requirements for effective performance in the banking sector. Business: Theory and Practice, 17(4), 317-324. doi:10.3846/btp.17.11127.

Elgin, C., \& Oztunali, O. (2012). Shadow economies around the world: model based estimates. [Bogazici University Department of Economics Working Papers, 5]. pp. 1-48.

Elgin, C., \& Schneider, F. (2013). Shadow economies in OECD countries: DGE vs. MIMIC approaches. [Bogazici University Department of Economics Working Papers, No. 2013/13].

EU Commission. (2013). Regulation (EU) No. 549/2013 of the European Parliament and of the Council of 21 May 2013 on the European system of national and regional accounts in the European Union Text with EEA relevance.

Eurostat Database. (2016). Eurostat: Building the system of national accounts - nonobserved sector. Retrieved December 15, 2016.

Eyal, I., \& Sirer, E. G. (2014, March). Majority is not enough: Bitcoin mining is vulnerable. In International Conference on Financial Cryptography and Data Security (pp. 436-454). Berlin Heidelberg: Springer. doi:10.1007/978-3-662-45472-5_28.

Duygun Fethi, M., Fethi, S., \& Turan Katircioglu, S. (2006). Estimating the size of the Cypriot underground economy: A comparison with European experience. International Journal of Manpower, 27(6), 515-534. doi:10.1108/01437720610690464.

Galdikienè, L. (2013). Bitkoinai - ateities valiuta ar vienadienè žvaigždè? [Bitcoins a future currency or an instant star]. Delfi News.

Galloppo, G., Paimanova, V., \& Aliano, M. (2015). Volatility and Liquidity in Eastern Europe Financial Markets under Efficiency and Transparency Conditions. Economics and Sociology, 8(2), 70-92. doi:10.14254/2071789X.2015/8-2/6.

Gaspareniene, L., \& Remeikiene, R. (2015). Digital shadow economy: A critical review of the literature. Mediterranean Journal of Social Sciences, 6(6S5), 402-409. doi:10.5901/mjss.2015.v6n6s5p402.

Gasparènienè, L., Remeikienè, R., \& Schneider, F. (2017). Concepts, motives and channels of digital shadow economy: consumer's attitude. Journal of Business Economics and Management, 18(2), 273-287. doi:10.3846/16111699.2016.1214620. 
Georgiou, G. M. (2007). Measuring the size of the informal economy: a critical review. Occasional Paper in Economics, 7(1).

Hatipoglu, O., \& Ozbek, G. (2011). On the political economy of the informal sector and income redistribution. European Journal of Law and Economics, 32(1), 69-87. doi:10.1007/s10657-010-9179-6.

Herwartz, H., Tafenau, E., \& Schneider, F. (2015). One share fits all? Regional variations in the extent of the shadow economy in Europe. Regional Studies, 49(9), 1575-1587. doi:10.1080/00343404.2013.848034.

Holt, T. J., Blevins, K. R., \& Burkert, N. (2010). Considering the pedophile subculture online. Sexual Abuse, 22(1), 3-24. doi:10.1177/1079063209344979.

Juškienè, G. (2015). Overview of the methods used to ensure exhaustiveness the national accounts of Lithuania. Lithuanian Department of Statistics.

Kaufmann, D., \& Kaliberda, A. (1996). Integrating the unofficial economy into the dynamics of post-socialist economies: A framework of analysis and evidence. [The World Bank, Policy Research Working Paper Series, No 1691]. doi:10.1596/1813-9450-1691.

Ključnikov, A., Belás, J., Kozubíková, L., \& Paseková, P. (2016). The Entreprenurial Perception of SME Business Environment Quality in the Czech Republic. Journal of Competitiveness, 8(1), 66-78. doi:10.7441/joc.2016.01.05.

Lackó, M. (1998). The hidden economies of Visegrad countries in international comparison: A household electricity approach. In Hungary: Towards a market economy. (pp. 128-152). New York: Cambridge University Press.

Lithuanian Department of Statistics. (2016). Informacinių technologiju naudojimas namy ūkiuose [Usage of information technologies in households] Official Statistics Database.

LFMI: Facts and Analyses. (2013). Lithuanian Free Market Institute: Ar atsiskaitymu grynaisiais ribojimas sumažins šešèlinę ekonomiką? [Will limitation of cash payments reduce shadow economy?].

Lithuanian International Transfer Advisory Website. (2013). Pinigu pervedimai. It: Tarptautiniu pinigu perlaidu bendroviu palyginimas [Comparison of international money transfer companies], LITAWeb.

Mayayise, T., \& Olusegun Osunmakinde, I. (2014). E-commerce assurance models and trustworthiness issues: an empirical study.
Information Management \& Computer Security, 22(1), 76-96. doi:10.1108/IMCS-01-2013-0001.

Miciuła, I. (2015). Financial innovations on the currency market as new instruments to risk management. Journal of International Studies, 8(1), 138-149. doi:10.14254/2071-8330.2015/8-1/12.

Musa, H. (2010). The Impact of the Single Euro Payments Area (SEPA). Journal of Competitiveness, 2(1), 41-51.

OECD Statistics. (2002). Organization for Economic Co-Operation and Development: Measuring the non-observed economy.

Putniņš, T. J., \& Sauka, A. (2014). Shadow Economy Index for the Baltic countries, 20092013. The Centre for Sustainable Business, SSE Riga.

Renooy, P., Ivarsson, S., van der WustenGritsai, O., \& Meijer, R. (2004). Undeclared Work in an Enlarged Union: an analysis of shadow work-an in-depth study of specific items. Brussels: European Commission.

Schneider, F., \& Buehn, A. (2013). Estimating the size of the shadow economy: methods, problems and open questions. [CESifo Working Paper Series No. 4448].

Schneider, F., \& Kearney, A. T. (2013). The shadow economy in Europe, 2013. Linz: Johannes Kepler Universitat.

Schneider, F., Raczkowski, K., \& Mróz, B. (2015). Shadow economy and tax evasion in the EU. Journal of Money Laundering Control, 18(1), 34-51. doi:10.1108/JMLC-09-2014-0027.

Schneider, F., \& Williams, C. C. (2013). The shadow economy. London: The Institute of Economic Affairs. Retrieved November 8, 2016 from https://iea.org.uk/wp-content/ uploads/2016/07/IEA \% 20Shadow $\% 20$ Economy\%20web\%20rev\%207.6.13.pdf.

Siddik, A., Sun, G., Kabiraj, S., Shanmugan, J., \& Yanjuan, C. (2016). Impacts of e-banking on performance of banks in a developing economy: empirical evidence from Bangladesh. Journal of Business Economics and Management, 17(6), 1066-1087. doi:10.3846/16111699.2015.1068219.

Simionescu, M., Lazányi, K., Sopková, G., Dobeš, K., \&Balcerzak,A.P. (2017). Determinants of Economic Growth in V4 Countries and Romania. Journal of Competitiveness, 9(1), 103116. doi:10.7441/joc.2017.01.07.

Simser, J. (2015). Bitcoin and modern alchemy: in code we trust. Journal of Financial Crime, 22(2), 156-169. doi:10.1108/JFC-112013-0067. 
Slozko, O., \& Pelo, A. (2014). The Electronic Payments as a Major Factor for Further Economic Development. Economics and Sociology, 7(3), 130-140. doi:10.14254/2071789X.2014/7-3/10.

Sookram, S., Watson, P. K., \& Schneider, F. (2009). Characteristics of households in the informal sector of an emerging economy. Applied Economics, 41(27), 3545-3559. doi:10.1080/00036840701493733.

Stachova, K., Stacho, Z., \& Vicen, V. (2017). Efficient involvement of human resources in innovations through effective communication. Business: Theory and Practice, 18(1), 33-42. doi:10.3846/btp.2017.004.

Statista Database. (2016). Statista: Bitcoin price index from November 2014 to November 2016 (in U.S. dollars). Retrieved from https:// www.statista.com/.

Štitilis, D., \& Laurinaitis, M. (2008). Alternative payment systems: Lithuanian outlook. Intellectual Economics, 2(4), 43-51.

Teobaldelli, D. (2011). Federalism and the shadow economy. Public Choice, 146(3-4), 269-289.

Teobaldelli, D., \& Schneider, F. (2012). Beyond the veil of ignorance: The influence of direct democracy on the shadow economy. [CESifo Working Paper MO3749]. Munich: University of Munich.

Vanini, P. (2012). Virtual Currency Schemes. Frankfurt am Main.

The United Nations Economic Commission for Europe: Non-observed economy in national accounts. (2003). Survey of national UNECE.

Trebicka, B. (2014). MIMIC model: A tool to estimate the shadow economy. Academic Journal of Interdisciplinary Studies, 3(6), 295.

Williams, C. C. (2006). The Hidden Enterprise Culture: Entrepreneurship and the Shadow Economy. Cheltenham: Edward Edgar.

Williams, C. C. (2009). Rationales for outsourcing domestic services to off-the-books workers. Journal of Economic Studies, 36(4), 343-354. doi:10.1108/01443580910973565.

Williams, C. C. (2010). Out of the shadows: explaining the undeclared economy in Baltic countries. Journal of Baltic Studies, 41(1), 3-22. doi:10.1080/01629770903525282.
Williams, C. C., \& Nadin, S. J. (2012). Tackling entrepreneurship in the informal economy: evaluating the policy options. Journal of Entrepreneurship and Public Policy, 1(2), 111-124. doi:10.1108/20452101211261408.

Williams, C. C., \& Nadin, S. (2013). Harnessing the hidden enterprise culture: Supporting the formalisation of off-the-books business start-ups. Journal of Small Business and Enterprise Development, 20(2), 434-447. doi:10.1108/14626001311326815.

Williams, C. C., Round, J., \& Rodgers, P. (2007). Beyond the formal/informal economy binary hierarchy. International Journal of Social Economics, 34(6), 402-414. doi:10.1108/03068290710751812.

Zandi, M., Singh, V., \& Irving, J. (2013). The impact of electronic payments on economic growth. Moody's Analytics: Economic and Consumer Credit Analytics.

Żelazny, R. (2015). Model of Information Society Measurement - Framework and Selected Outcomes. Economics and Sociology, 8(3), 245-259. doi:10.14254/2071789X.2015/8-3/17.

Ligita Gasparènienè, Dr. Mykolas Romeris University ligitagaspareniene@mruni.eu

doc. Dr. Yuriy Bilan Research Associate

Tomas Bata University in Zlin Faculty of Management and Economics Centre of Applied Economic Research yuriy_bilan@yahoo.co.uk

Rita Remeikienè, Dr. Mykolas Romeris University rita.remeikiene@mruni.eu

Prof. habil. dr. Romualdas Ginevičius Vilnius Gediminas Technical University romualdas.ginevicius@vgtu.It

Dr. Martin Čepel, PhD., MBA LIGS University LLC Honolulu cepel@benzinol.com 


\section{Abstract}

\section{THE METHODOLOGY OF DIGITAL SHADOW ECONOMY ESTIMATION}

\section{Ligita Gasparènienè, Yuriy Bilan, Rita Remeikienè, Romualdas Ginevičius, Martin Čepel}

The article introduces a new methodology of digital shadow economy estimation, which is based on the principles of the MIMIC method. This new methodology complements traditional methodologies of shadow economy estimation with such a component as digital shadow economy.

Our analysis of the most popular today methods of shadow economic estimation proves that, despite some of its drawbacks, the MIMIC model can be treated as the most comprehensive and appropriate method for such calculations since it takes into account both causal and indicators of shadow economy.

As the causal variables here, as applied to digital shadow economy, we use household access to the Internet and IT overall, the volume of non-cash payments and the use of most advanced financial instruments. While as the indicators of the digital shadow economy spread we use: the volume of non-cash payments at online platforms, the frequency of cryptocurrency payments, and the cost of parcels to which customs duties have not been applied.

For further empirical verification of the model proposed here, numerical values of both causal variables and indicators would be necessary. Unfortunately, official statistical sources are unable to provide such data in full volume, especially when it comes to cryptocurrencies and other informal payments. Thus, in our further research we plan to not only prove the practical applicability of the offered here model for estimations of digital shadow economy size as well as overall size of shadow economy on the examples of particular countries, but also to accumulate the necessary statistics for such calculations.

Key Words: Shadow economy, digital shadow economy, indicators of shadow economy, causal variables, MIMIC model.

JEL Classification: G34, M12.

DOI: 10.15240/tul/001/2017-4-002 